\title{
Effect of dietary exogenous phytase on laying performance of chicken at older ages
}

\author{
NJ Lucky', MAR Howlider ${ }^{2}$, MA Alam*3, MF Ahmed ${ }^{2}$ \\ ${ }^{1}$ Department of Livestock Services, Bangladesh; ${ }^{2}$ Department of Poultry Science, Bangladesh Agricultural \\ University, Mymensing 2202, Bangladesh; ${ }^{3}$ System Research Division, Bangladesh Livestock Research Institute, \\ Savar, Dhaka 1341, Bangladesh
}

\begin{abstract}
A total of 48 Shaver- 579 chicken layers aged between 85 to 94 weeks were reared in individual cages and given a basal diet amounting to $115 \mathrm{~g}$ feed/bird/day. The basal diet fortified with $0.05,0.10$ or $0.15 \%$ RenaPhytase- 400 constituted of 3 experimental diets to see the effects of exogenous phytase on egg production and egg quality. Results indicated that increasing level of exogenous phytase in diet almost linearly $(p<0.05)$ increased egg production and feed conversion but did not affect egg quality. Providing phytase in the diet at $0.05,0.10$ and $0.15 \%$ increased egg production by $11.86,22.2$ and $24.58 \%$, respectively. It was shown that highest egg production was found at $0.15 \%$ phytase levels in diet. It can be concluded that egg production of aged hen could be increased by adding said amount of exogenous phytase in the diet.
\end{abstract}

Key words: Exogenous phytase, egg production, layer,

Bangladesh Animal Husbandry Association. All rights reserved. Bang. J. Anim. Sci. 2014. 43 (1): 52-55

\section{I ntroduction}

Egg production of hens starts at about 19 weeks of age. It rises sharply to a peak at around 26-28 weeks and then gradually declines at older ages. Hens are usually reared up to 72-76 weeks of age. Beyond this, egg production is decreased to affect economic production. Both egg production and dietary phosphorus (P) utilization are depressed (Al-Batshan et al. 1994) at older ages. It is not clear whether decreased egg production at older ages is related to poor $P$ utilization or decreased availability of $P$. Whether such an age related diminished egg production could be corrected by supplying exogenous phytase. Plant based feed ingredients are used in poultry diet with variable concentrations and about 50-80 percent $P$ is present in the form of insoluble complex, phytic acid, which cannot be utilized by poultry (Eeckhout and De Paepe 1994). Phosphorus is one of the major minerals required by hens and plays a major role in several metabolic processes. Phosphorus and calcium are very important for layers (Roland and Gordon 1996), to optimize egg production and shell quality. Phytase hydrolyses phytic acid to inositol and phosphoric acid (Liu et al. 1998; Leske and Coon 1999), leading to increased $P$ availability to poultry. The use of phytase in layer diets also reduces the requirements for inorganic $P$ (Gordon and Roland 1997; Carlos and Edwards 1998 and Um and Paik 1999). Different levels of exogenous phytase increased egg production in chicken at younger ages (Hughes et al. 2008; Augspurger et al. 2007; Wu et al. 2006; Lim et al. 2003 and Boling et al. 2000). Researchers are scanty on relations between $\mathrm{P}$ availability and egg production of hens at older ages. Therefore, the study was undertaken to assess and quantify the effects of adding dietary exogenous phytase on egg production and egg quality of chicken at older ages.

\section{Materials and Methods}

\section{Experimental design, birds and diets}

The experiment was conducted for a period of 9 weeks between 85 and 94 weeks age of hen (Shaver 579) at Bangladesh Agricultural University poultry farm to have the effects of exogenous phytase (Rena-Phytase-400) on egg production and egg quality in laying hens at older ages. A total of 48 Shaver 579 layers (85 weeks age) were 


\section{Exogenous phytase in broiler diet}

randomly distributed to individual cages. Each bird received $115 \mathrm{~g}$ of feed daily with $0,0.05,0.10$, and $0.15 \%$ exogenous phytase during experiment. The basal diet contained $895 \mathrm{~g}$ dry matter, $2860 \mathrm{kcal}$ metabolizable energy, $35 \mathrm{~g}$ crude fibre, $175 \mathrm{~g}$ crude protein, $45 \mathrm{~g}$ crude fat, $40 \mathrm{~g}$ calcium, $4.5 \mathrm{~g}$ available phosphorus, $8 \mathrm{~g}$ lysine, $4.2 \mathrm{~g}$ methionine and $125 \mathrm{~g}$ ash per $\mathrm{kg}$ diet. They were exposed to a 16 hours of continuous lighting (natural light + artificial light) in an open sided house. Records were kept on initial and final live weight, egg production and egg weight per replication. Feed conversion ratio, egg production percent, survivability and some egg quality parameters were calculated.

\section{Statistical analysis}

The data were analyzed using the GENSTAT Statistical Program for a completely randomized design (CRD). Analysis of variance was performed to compare data among the levels of exogenous phytase. Significant differences were isolated by calculating least significant differences.

\section{Results and Discussion}

The results of the experiment are presented in Table 1 . It appeared that egg production, egg mass production and feed conversion ratio were increased almost linearly $(p<0.05)$ at increasing level of dietary phytase. Moreover, final body weight and egg weight of laying hens did not differ significantly $(p>0.05)$ among different dietary levels of phytase. Shell percent, shell thickness, shape index, albumen index, yolk index, haugh unit, yolk percent, Yolk colour score and shell weight had no relation with the levels of dietary exogenous phytase $(p>0.05)$.

Increased egg production was obtained on increasing dietary exogenous phytase in diets of chicken (Table 1 ). This result agrees with the findings of Hughes et al. (2008), Augspurger et al. (2007), Wu et al. (2006), Lim et al. (2003) and Boling et al. (2000). Providing phytase in the diet at $0.05,0.10$ and $0.15 \%$ increased egg production by $11.86,22.2$ and $24.58 \%$, respectively. Results shown, highest egg production was found on $0.15 \%$ phytase levels. Availability and retention of $\mathrm{P}$ and $\mathrm{Ca}$ are decreased in hens at older ages (AlBatshan et al. 1994). On the other hand, egg production is also depleted with the advance of age (Banerjee 1992). Such results imply that there may be a relation between decreased availability of $P$ and egg production in hens at older ages.

Table 1. Effects of exogenous dietary phytase on production and quality of egg in older hens (85-94 weeks)

\begin{tabular}{|c|c|c|c|c|c|c|}
\hline \multirow[t]{2}{*}{ Parameters } & \multicolumn{5}{|c|}{ Exogenous phytase (\%) } & \multirow{2}{*}{$\begin{array}{l}\text { Sig. } \\
\text { level }\end{array}$} \\
\hline & 0 & 0.05 & 0.10 & 0.15 & $\overline{\text { Mean }}$ & \\
\hline Initial weight (g/bird) & 1782 & 1755 & 1808 & 1723 & 1767 & NS \\
\hline Final weight (g/bird) & 1808 & 1783 & 1800 & 1792 & 1796 & NS \\
\hline Egg production (\%) & $59.0 \mathrm{c}$ & $66.0^{b}$ & $72.1^{\mathrm{a}}$ & $73.5^{\mathrm{a}}$ & $67.60^{b}$ & ** \\
\hline Egg weight (g/egg) & 64.95 & 65.10 & 64.38 & 65.46 & 64.97 & NS \\
\hline Egg mass (g/b/d) & $38.2^{c}$ & $43.0^{b}$ & $46.4^{a}$ & $48.1^{\mathrm{a}}$ & $43.90^{\mathrm{b}}$ & ** \\
\hline FCR (Fl/Egg mass) & $3.25^{\mathrm{a}}$ & $2.72^{b}$ & $2.53^{b}$ & $2.43^{b}$ & $2.73^{b}$ & * \\
\hline Shell weight (g) & 6.283 & 6.208 & 6.367 & 6.325 & 6.30 & NS \\
\hline Shell (\%) & 9.61 & 9.55 & 10.27 & 10.30 & 9.93 & NS \\
\hline Shell thicknes & 0.382 & 0.377 & 0.385 & 0.397 & 0.39 & NS \\
\hline Shape index & 72.58 & 72.32 & 73.27 & 73.20 & 72.84 & NS \\
\hline Albumen inde & 0.040 & 0.037 & 0.035 & 0.034 & 0.036 & NS \\
\hline Yolk index & 0.400 & 0.390 & 0.388 & 0.383 & 0.390 & NS \\
\hline Haugh unit & 51.8 & 46.7 & 47.6 & 47.1 & 48.3 & NS \\
\hline Yolk colour score & 7.83 & 8.17 & 7.92 & 7.67 & 7.90 & NS \\
\hline Yolk (\%) & 25.95 & 24.24 & 25.84 & 25.89 & 25.48 & NS \\
\hline
\end{tabular}

$\mathrm{Fl}$, feed intake; means with different superscript(s) differed significantly (*, $\mathrm{p}<0.05$; **, p<0.01); NS, not significant

The remarkably higher egg production on different doses of phytase gave an impression that the economic productive life and egg production of hens can be extended by increased $\mathrm{P}$ availability. The possible relation of phytase, availability of $\mathrm{Ca}$ and $\mathrm{P}$ and egg production have been supported by Francesch et al. 2005; Cabuk et al. 2004; Um and Paik 1999; Gordon and Roland (1998). Viveros et al. (2002) suggested that phytase supplementation increased $\mathrm{Ca}$ retention. Increased feed conversion of hens at increasing level of exogenous phytase obtained is supported by Francesch et al. (2005) who reported that supplementation of microbial dietary phytase $\left(0,300\right.$ and $\left.600 \mathrm{Ukg}^{-1}\right)$ improved egg production, egg weight and feed conversion in laying hens. Phytase supplementation with $3.0 \mathrm{~g}$ available $P / k g$ diet improved $(p<0.05)$ feed conversion (Çabuk et al. 2004). Jalal and Scheideler (2001) also reported that phytase supplementation containing $3.5 \mathrm{~g}$ non-phytate $\mathrm{P} / \mathrm{kg}$ $(p<0.05)$ improved the feed conversion of laying 
Lucky et al. (2014) Bang. J. Anim. Sci. 43 (1): 52- 55

hens. However, contradicting current results, Van Der Klis et al. (1997) and Um and Paik (1999) reported that phytase supplementation to the diets containing 3.3 and $3.7 \mathrm{~g}$ available $\mathrm{P} / \mathrm{kg}$ had no beneficial effect on feed conversion. The type of phytase use may be responsible for the contradictory results. Moreover, several previous reports demonstrated that supplementation of phytase generally enhanced egg production of chicken, coupled with increased egg weight (Um and Paik 1999; Silversides et al. 2006), which was also associated with decreased dietary non phytate phosphorus level (Wu et al. 2006). No significant differences $(p>0.05)$ in shape index, albumen index, yolk index, yolk percent, yolk colour and haugh unit were found among the levels of phytase in the current study which is supported by Park et al. (2009) and Um and Paik (1999).

\section{Conclusion}

It may be concluded that increasing level of exogenous phytase in diet almost linearly increased egg production and feed conversion ratio but did not affect egg quality. Decreased egg production in older ages of hens could be corrected to some extent by adding exogenous dietary phytase at $0.15 \%$ levels in the diet.

\section{References}

Al-Batshan HA, Scheideler SE, Black BL, Garlich JD, Anderson KE (1994). Duodenal calcium uptake, femur ash, and eggshell quality decline with age and increase following molt. Poultry Science, 73: 1590-1596.

Augspurger NR, Webel DM, Baker DH (2007). An Escherichia coli phytase expressed in yeast effectively replaces inorganic phosphorus for finishing pigs and laying hens. Journal of Animal Science, 85: 1192-1198.

Banerjee GC (1992). Egg producing carrier of a laying hen. Poultry, Third edition, P. 45-46.

Boling SD, Douglas MW, Johnson ML, Wang $X$, Parsons CM, Koelkebeck KW, Zimmerman RA (2000). The effects of dietary available phosphorus levels and phytase on performance of young and older laying hens. Poultry Science, 79: 224-230.

Cabuk M, Bozkurt M, Kyrkpynar F, Ozkul H (2004). Effect of phytase supplementation of diets with different levels of phosphorus on performance and egg quality of laying hens in hot climatic conditions. South African Journal of Animal Science, 34: 13-17.

Carlos AB, Edwards HM (1998). The effect of 1.25dihydroxycholicalciferol and phytase on the natural phytate phosphorus utilization by laying hens. Poultry Science, 77: 850-858.

Eeckhout W, De Paepe M (1994). Total phosphorus, phytate phosphorus and phytase activity in plant feedstuffs. Animal Feed Science and Technology, 47: 19-29.

Francesch M, Broz J, Brufau J (2005). Effects of an experimental phytase on performance, egg quality, tibia ash content and phosphorus bioavailability in laying hens fed on maize- or barley-based diets. British Poultry Science 46: 340-348.

Gordon RW, Roland DASr (1997). Performance of commercial laying hens fed various phosphorus levels, with and without supplemental phytase. Poultry Science, 76: 1172- 1177.

Gordon RW, Roland DASr (1998). Influence of supplemental on calcium and phosphorus utilization in laying hens. Poultry Science, 77: 290-294.

Hughes AL, Dahiya JP, Wyatt CL, Classen $H L$ (2008). The efficacy of quantum phytase in a forty-week production trial using white leghorn laying hens fed corn-soybean mealbased diets. Poultry Science, 87: 1156-1161.

Jalal MA, Scheideler SE (2001). Effect of supplementation of two different sources of phytase on egg production parameters in laying hens and nutrient digestibility. Poultry Science, 80: 1463-1471.

Leske KL, Coon CN (1999). A bioassay to determine the effect of phytase on phytate phosphorus hydrolysis and total phosphorus retention of feed ingredients as determined with broilers and laying hens. Poultry Science, 78: 11511157.

Lim HS, Namkung H, Paik IK (2003). Effects of phytase supplementation on the performance, egg quality and phosphorus excretion of laying hens fed different levels of dietary calcium and non phytate phosphorus. Poultry Science, 82: 92-99. 


\section{Exogenous phytase in broiler diet}

Liu BL, Rafiq A, Tzeng YM, Rob A (1998). The induction and characterization of phytase and beyond. Enzyme Microbiology Technology, 22: 415-424.

Park KW, Rhee AR, Um JS, Paik IK (2009). Effect of dietary available phosphorus and organic acids on the performance and egg quality of laying hens. Applied Poultry Research, 18: 598-604.

Roland DA, Gordon RW (1996). Metabolism and role of phosphorus, calcium and vitamin D3 in layer nutrition. Journal of Applied Poultry Research, 125-136.

Silversides FG, Scott TA, Korver DR, Afsharmanesh M, Hruby M (2006). A study on the interaction of xylanase and phytase enzymes in wheatbased diets fed to commercial white and brown egg laying hens. Poultry Science, 85: 297-305.
Um JS, Paik IK (1999). Effects of microbial phytase supplementation on egg production, eggshell quality and mineral retention of laying hens fed different levels of phosphorus. Poultry Science, 78: 75-79.

Van Der Klis JD, Versteegh HAJ, Simons PCM, Kies AK (1997). The efficacy of phytase in cornsoybean meal-based diets for laying hens. Poultry Science, 76: 1535-1542.

Viveros A, Brenes A, Arija I, Centeno C (2002). Effects of microbial phytase supplementation on mineral utilization and serum enzyme activities in broiler chicks fed different levels of phosphorus. Poultry Science, 81: 11721183.

Wu G, Liu Z, Bryant MM, Roland SrDA (2006). Comparison of Natuphos and Phyzyme as phytase sources for commercial layers fed corn-soy diet. Poultry Science, 85: 64-69. 